\title{
Models of reflection of kimberlite pipes of North-East of Botswana in eolian haloes of dispersion
}

\author{
V. Ustinov ${ }^{1}$, B. Mosigi' ${ }^{2}$, I. Kukui ${ }^{1}$, E. Nikolaeva ${ }^{1}$, J. Campbell ${ }^{2}$, \\ Yu. Stegnitskyi ${ }^{1}$, M. Antashchuk ${ }^{1}$ \\ ${ }^{1}$ ALROSA, Saint-Petersburg, Russia,UstinovVN@alrosa.ru,KukuyIM@alrosa.ru \\ ${ }^{2}$ Botswana Diamonds, London,UK,Bmosigi@gmail.com, James@botswanadiamonds.co.uk
}

The Late Cretaceous kimberlite pipes of the Orapa field (Figure 1) breaking through the Lower Jurassic basalts of Stormberg Group manifest themselves in haloes of dispersion of kimberlite indicator minerals (KIMs) enclosed in talus, proluvial, biogenic (in termite mounds), eolian and other sediments.

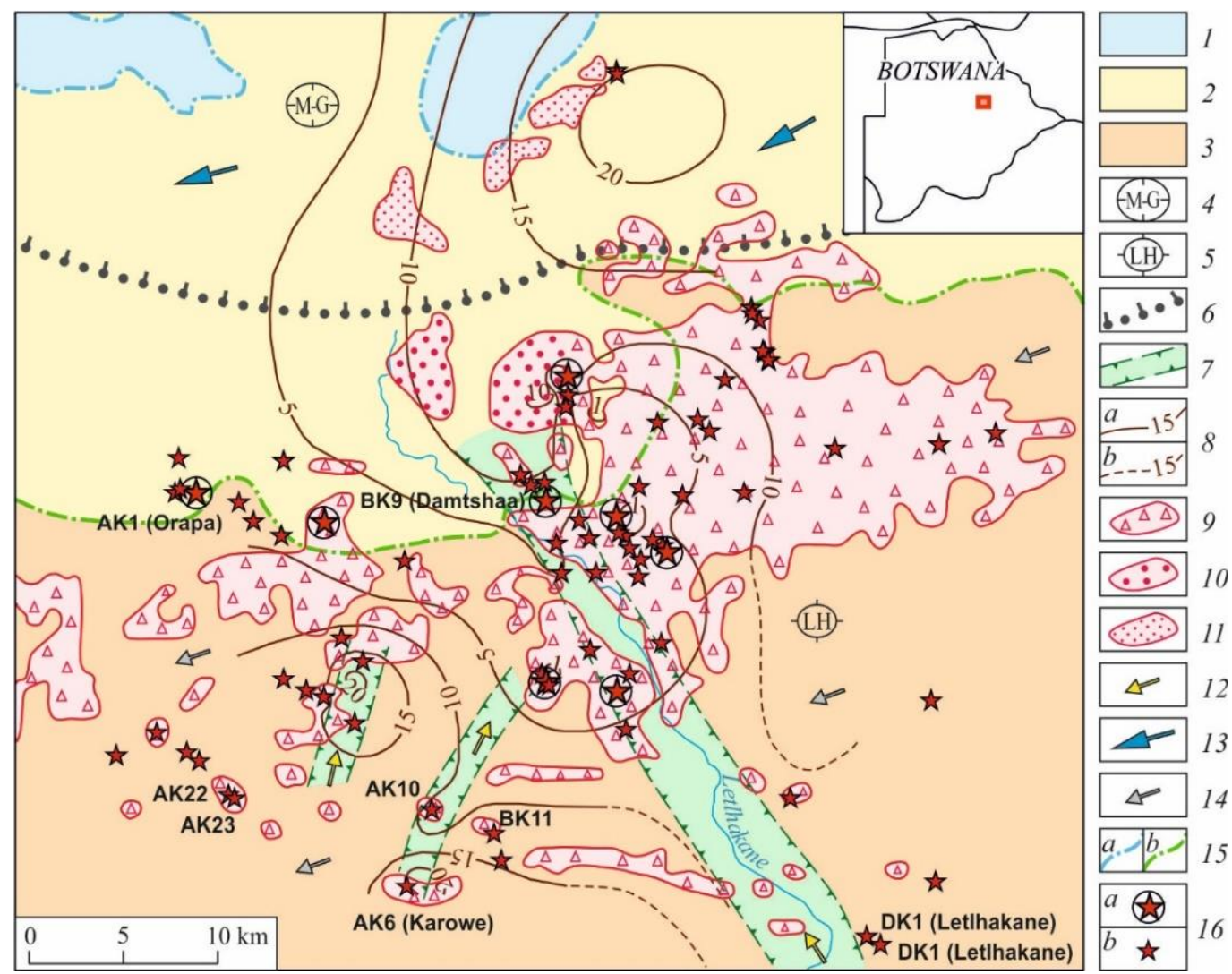

Figure 1: Eolian haloes of dispersion of KIMs in the area of Orapa kimberlite field.

1-7 - forms and elements of the Neogene-Quaternary relief: megaforms ( 1 - subhorizontal low accumulative plain, 2 - gently-sloping denudation-accumulative plain, 3 - slightly elevated denudation-accumulative plain); macroforms (4 - depression: Makgadikgadi, M-G; 5 - elevation: Letlhakane, LH); 6 - boundaries of macroforms; mesoforms (7-river valleys and paleovalleys); 8 - isopaches of the Neogene-Quaternary sediments of Kalahari Group ( $a$ - reliable, $b$ - supposed); 9-11 - eolian haloes of dispersion of KIMs formed due to wind reworking of: 9 - talus and proluvial sediments, 10 - deltaic, 11 - continental and basinal of different genesis; $12-14$ - directions of transportation of kimberlite minerals: 12 - water streams, 13 - wind, 14 - waves; 15 - standing levels of an inland basin ( $a$ - minimal, $b$ - maximal); 16 - the Early Cretaceous kimberlite pipes ( $a$ - diatreme shaped, $b-$ pear shaped and pipes-embryos).

The most widely developed in the area are eolian sands of the Kalahari Group, overlying pipes and forming the surface of relief. In the Orapa field they contain pyropes and picroilmenites almost on the entire territory. These are of different degrees of abrasion (I - unabraded, II - slightly, III - 
moderately, IV - extensively, V - very extensively abraded). The combination of kimberlite minerals that come from different sources, situated on short, moderate or long distances often occurs in eolian haloes of dispersion.

KIMs of high (IV-V) degrees of abrasion which are transitory create a general mineralogical blanket (up to 10 gr./20 1) within the Orapa field and adjacent territories. They were accumulated in geomorphological traps (depressions, valleys, ancient shorelines etc.), where they form a higher contents of minerals (20-30 gr./20 1 or more). On the examples of known kimberlite pipes (AK10, AK22, AK23 and others), which are overlain by sands of the Kalahari group up to 20 meters thickness, the eolian haloes of dispersion of short travel are characterized by the presence of KIMs mainly of I-II degrees of abrasion, and are situated close to kimberlite bodies. A change in the morphological features and degrees of abrasion of pyropes and picroilmenites has been traced with the distance from the primary sources (Figure 2).

\begin{tabular}{|c|c|c|c|c|}
\hline Above the pipe & $100-200 \mathrm{~m}$ & $300-400 \mathrm{~m}$ & $500-600 \mathrm{~m}$ & $700-800 \mathrm{~m}$ \\
\hline $\mathrm{I}$ & $\mathrm{I}-\mathrm{II}$ & $\mathrm{II}$ & $\mathrm{II}-\mathrm{III}$ & $\mathrm{III}$ \\
\hline & & & \\
\hline & & & \\
\hline & & & & \\
\hline & & & & \\
\hline
\end{tabular}

Figure 2: Change in the morphological features and degrees of abrasion (I-III) of picroilmenite and pyrope grains at different distances from AK10 pipe.

The eolian haloes of short travel covering gentle slopes of plains often have sizes of $500 \times 1000$ $\mathrm{m}$ and are of oval or conical shape. Haloes are characterized by a reduction of the contents of unabraded and slightly abraded grains $(+2 \mathrm{~mm},-2+1 \mathrm{~mm}$ and $-1+0,35 \mathrm{~mm})$ from hundreds and thousands gr./20 1 above the pipe to $5 \mathrm{gr} / 201$ of $-1+0,35 \mathrm{~mm}$ size at a distance of up to $1 \mathrm{~km}$. A sharp reduction of contents (up to $10 \mathrm{gr} . / 20 \mathrm{l}$ ) at a distance of 100-200 $\mathrm{m}$ from the source is a typical feature (Figure 3). At a distance of 500-600 m slightly abraded picroilmenites were found only in fine size $(-0,35 \mathrm{~mm})$. Pyropes of I and II degrees in fraction $+1 \mathrm{~mm}$ are recorded in the surface sediments above the body, at a distance of 100 $\mathrm{m}$ they are established only in $-0,35 \mathrm{~mm}$ size. 
Some of the eolian haloes are enclosed in the low-contrast negative forms of relief which occur above the kimberlite pipes. KIMs in the surface sediments were abraded and broken up under the influence of wind and temporary water flows almost above the sources. Grains of III degree of abrasion can be found along with kimberlite minerals of I-II degrees.

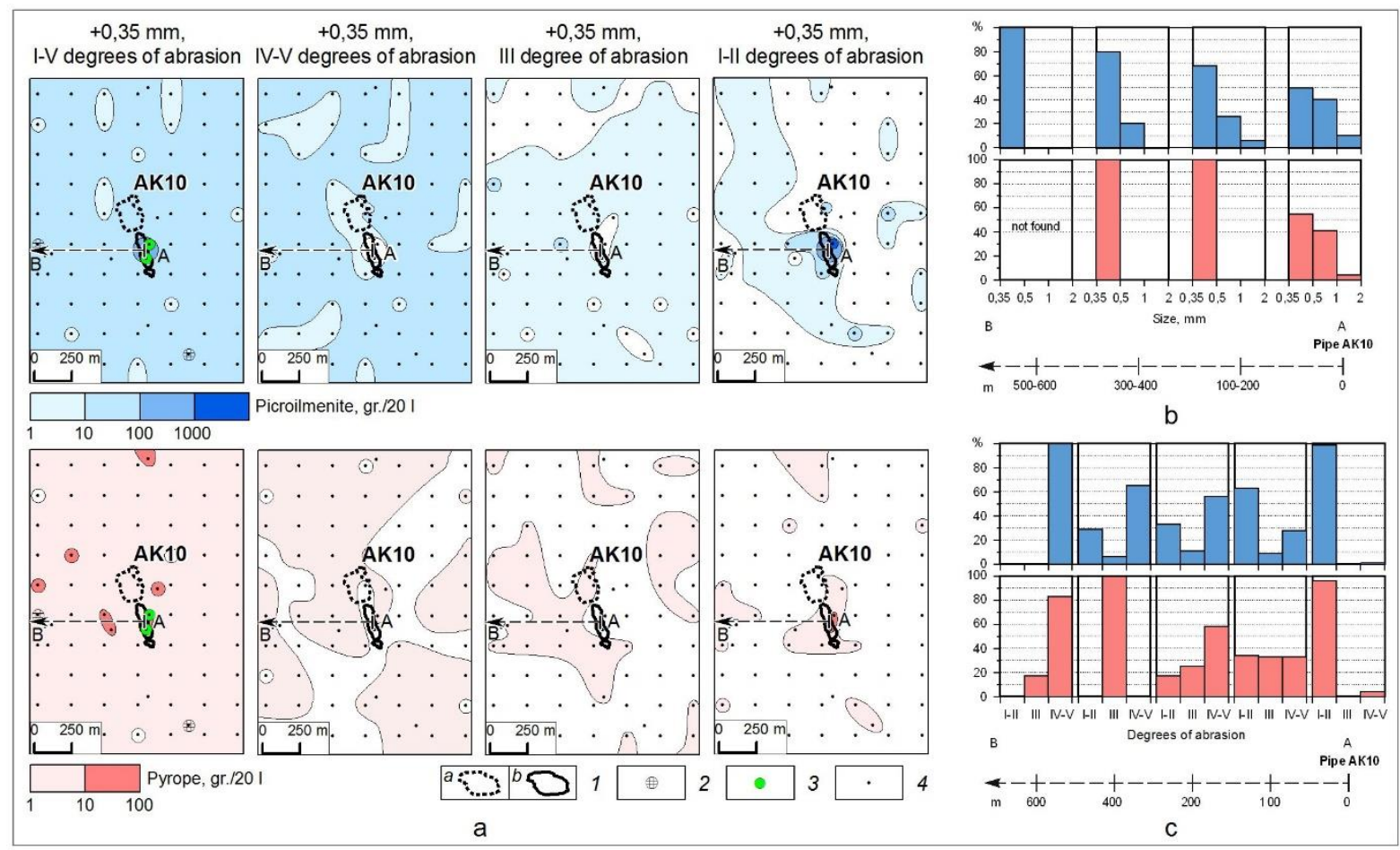

Figure 3: Haloes of dispersion of pyropes (red) and picroilmenites (blue) in area of AK10 pipe (a), distribution of kimberlite minerals according to size (b) and to degree of mechanical abrasion (c) on profile $A B$ in area of AK10 kimberlite pipe.

1 - contour of kimberlite pipe in enclosing rocks (basalts): $a$ - under basalts, $b-$ on the surface of basalts; 2 occurrences of chrome-spinels; 3 - occurrences of chrome-diopsides, 4 - heavy concentrate samples.

As a result of studies, models of reflection of kimberlite bodies in eolian haloes of dispersion of KIMs were created on the basis of analysis of contents, fractional composition and typomorphic features of minerals. It has been established that it is necessary to take into account pyropes and picroilmenites only of I-II degrees of abrasion in fraction $+0,35 \mathrm{~mm}$ for the contrast delineation of haloes of short travel. It is shown that during prospecting works it is advisable to compile the mineral maps of KIMs distribution (separately for pyropes and picroilmenites) in the surface sediments by the degree of abrasion and grain size. It is important to note that even single grains of unabraded KIMs or those with a slight degree of abrasion found in eolian sediments have important prospecting value, and may indicate the proximity of the primary source. 